\title{
CHANGES IN TOTAL PHENOLIC COMPOUNDS AND ANTIOXIDANT ACTIVITY DURING DOMESTIC PROCESSING OF SOME CEREAL GRAINS \\ Ramadan, B.R. ${ }^{1}$; M. A. Sorour ${ }^{2}$ and M. A. M. Kelany ${ }^{2}$ \\ ${ }^{1}$ Food Sci. \& Tech. Dept., Fac. of Agric., Assiut University, Egypt. \\ ${ }^{2}$ Food Sci. Dept., Fac. of Agric., Sohag University, Egypt
}

\begin{abstract}
The aim of this work was to investigate the changes in total phenolic compounds content and free radical scavenging abilities against the stable 2,2-diphenyl-1picrylhydrazyl (DPPH assay) during soaking and germination of three cereal grains; wheat (Sids 1), corn (H310 White) and sorghum (Giza 15). Total phenolic compounds in wheat, sorghum and corn raw grains were $381.4,288.5$ and $204 \mathrm{mg} / 100 \mathrm{~g}$, respectively. Soaking and germination processes showed significant decrease in total phenolic compounds. Losses of total phenols during soaking for $12 \mathrm{hr}$ were 15.18 , 14.9 and $5.96 \%$ of its initial values in wheat, sorghum and corn raw materials, respectively. Germination process for $48 \mathrm{hr}$ led to decrement of total phenols ranged from $39.3-43.95 \%$ of its initial values in studied raw cereal grains. The DPPH radical scavenging activity decreased during soaking and germination processes of cereal grains.
\end{abstract}

\section{INTRODUCTION}

Grains in particular, are a major source of antioxidants in our daily diets. The main antioxidative components in grain are classified as phenolic compounds such as anthocyanins, tannins, and ferulic acid, and other substances (Tome' et al., 2004). Whole grain products are recommended for healthy diets as being recognized sources of dietary fiber and antioxidant substances (Ragaee et al., 2006). Consumption of foods containing rich antioxidant activity substances, such as grains, vegetables, and fruits, may prevent many diseases and promote good health (Willet, 1994 and Temple, 2000)

Soaking, germination and pressure-cooking proved to be effective household strategies to reduce the levels of polyphenols and tannins in grains (Shweta, et al., 2010). The process of cereal seeds germination has been used for centuries for the purpose of softening the kernel structure, improving its nutritional value, and reducing anti-nutritional effects. In fact, the germination process is also one of methods used to improve the functionality of oat seed protein (Kaukovirta-Norja, et al., 2004). Recently, El-Refai et al (2012) found that germination process had positive effect to improve the bioactive compounds content as total phenolic anf flavonoids of barely and oat grains. In general soaking period was reported to have pronounced effects on the vitamin levels and anti-nutritional factors present in natural foods (Fadahunsi, 2009). Radical scavenging is the main mechanism by which antioxidants act in foods. Several methods have been developed including 2, 2-diphenyl-1-picrylhydrazyl (DPPH) and 2,20-azinobis (3ethylbenzothiazoline-6-sulphonic acid) (ABTS) radical scavenging methods. The DPPH radical, is widely used to evaluate the free radical scavenging 
activity of hydrogen donating antioxidants in many plant extracts (Kumar et al., 2011)

The aim of this work was to investigate the changes in total phenolic content and free radical scavenging abilities against the stable 2,2-diphenyl1-picrylhydrazyl (DPPH assay) during soaking and germination of three cereal grains cultivars, namely wheat (Triticum aestivum L.) Sids 1, corn (Zea maiys L.) Hybrid 310 and sorghum (Sorghum bicolor L.) Giza 15 collected from Sohag Governorate, Egypt.

\section{MATERIALS AND METHODS}

Materials:

Grains: Three cereal grains, including wheat (Triticum aestivum L.) Sids 1, corn (Zea maiys L.) Hybrid 310 and sorghum (Sorghum bicolor L.) Giza 15 collected from Sohag Governorate, Egypt.

Chemicals: DPPH (2, 2-diphenyl-1-picrylhydrazyl), 6-hydroxy-2, 5, 7, FolinCiocalteau reagent, acetic acid were purchased from Sigma-Aldrich (St. Louis, MO). Methanol, ethanol, hexane, and ethyl acetate were HPLC grade.

Technological processes:

Soaking: Grains samples were soaked in water $(1: 5, \mathrm{w} / \mathrm{v})$ at room temperature for $12 \mathrm{hr}$, water was changed every $6 \mathrm{hr}$ (Abdel-Gawad, 1993).

Germination: Soaked grains samples were geminated in betry dishes coating with moistened filter paper at room temperature for 12, 24, 36 and 48 hr (Youssef et al., 1987).

Milling: All soaked and germinated grains were dried then conditioned by rising its moisture content up to $14 \%$, then left for $24 \mathrm{hr}$ as tempering time. Milling was run in a Buhler experimental mill (type 212) by progressively receiving the whole flour (Sorour, M. A 1997).

Analytical methods:

AOAC (2000).

Moisture, protein, fat and ash contents was determined according to

Total carbohydrate content of grains was calculated by difference.

Potassium, calcium, iron, and zanic were determind using Perkin Elmer Atomic Absorption Spectero-photometer 2380. Phosphorus content was determind by Specter-photometer according to AOAC (1980).

Extraction of total antioxidants:

Ten grams of dry sample were ground fine using a coffee grinder, then weighed and transferred into a test tube $(25 \times 150 \mathrm{~mm})$. For extraction; $40 \mathrm{~mL}$ of methanol were added in a test tube and vortexes to mix with the sample well triplicate. The test tubes were capped and placed in a $60^{\circ} \mathrm{C}$ water bath for $20 \mathrm{~min}$. The tubes were vortexed twice during the incubation. Then, the solvent layer from each tube was separated by centrifugation at 2000 rpms for $15 \mathrm{~min}$.

The solvent supernatant was transferred to clean, previously weighed and labeled test tubes. The residue was mixed with $20 \mathrm{~mL}$ of the same solvent again and vortexed. The solvent supernatant was combined with the previous one. The tube with supernatant was then placed in a vacuum 
centrifuge evaporator to remove solvent. The dried extract in the tube was weighed to measure the extraction yield of the samples. All samples were kepte at $-20^{\circ} \mathrm{C}$ prior to testing (Oufnac, 2006).

Determination of total phenolic compound content:

The total phenolic content of whole flour extract was determined using Folin-Ciocalteau reagent (Velioglu et al., 1998).

DPPH radical scavenging determination:

The antioxidant activity of phenolic compounds was measured in terms of hydrogen donating or scavenging ability, using the stable radical DPPH (2, 2-diphenyl-1-picrylhydrazyl) according to the colorimetric method described by Brand-Williams et al (1995).

Statistical analysis:

All soaking and germination processes were performed in triplicate. The data were expressed as mean \pm standard deviation. The analyses were processed using Excel 2003 software.

\section{RESULTS AND DISCUSSION}

\section{Gross chemical composition of studied grains:}

The results in Table (1) show the chemical composition and minerals of studied cereal grains cultivars. The data reveale that corn grain has the highest level of fat content, while wheat grain has highest protein content . The levels of protein, fat, ash and carbohydrates vary depending on the type of grain cultivar. Data of the average values of minerals revealed that potassium and phosphorus were the predominate elements present in all grains under investigation. The chemical composition of the studied grains has the same trend with that showed in the food composition table for Egypt (FCTE, 2006).

Table (1): Gross chemical composition of wheat, corn and sorghum (on dry weight basis).

\begin{tabular}{|c|c|c|c|c|c|c|c|c|c|}
\hline \multirow{2}{*}{ Cultivars } & \multirow{2}{*}{ Protein \% } & Fat \% & \multirow{2}{*}{ Ash \% } & $\begin{array}{c}\text { Carbohy- } \\
\text { drate \% }\end{array}$ & \multicolumn{5}{|c|}{ Minerals mg/100g } \\
\hline Wheat Sids1 & 12.73 & 0.57 & 1.57 & 85.13 & 8.04 & $\mathbf{P}$ & $\mathbf{C a}$ & $\mathbf{K}$ & $\mathbf{Z n}$ \\
\hline Sorghum Giza15 & 12.29 & 1.43 & 0.52 & 85.76 & 9.92 & 118.50 & 86.24 & 127.40 & 1.18 \\
\hline Corn H310 & 9.56 & 1.99 & 1.77 & 86.68 & 6.66 & 273.67 & 68.60 & 154.84 & 4.45 \\
\hline
\end{tabular}

\section{Effect of soaking and germination on phenolic compounds content:}

The results presented in Table (2) and Fig. (1) show the effect of soaking as phenolic contents of wheat, corn and sorghum. Wheat has higher phenolic content those corn and sorghum grains. Phenolic contents of wheat, corn and sorghum raw samples were 381.4, 288.5, and $204.0 \mathrm{mg}$ (GAE) $/ 100 \mathrm{~g}$, respectively. The phenolic contents has decreased to $84.82 \%$ of its initial value in the wheat grains after soaking for $12 \mathrm{hr}$, while it was 94.04 and $85.10 \%$ of their initial values of corn and sorghum grains. These results lower than those obtained by Glennie (1983) who reported that concentration of total phenolic of white sorghum ranged from 80 to $100 \mathrm{mg} / 100 \mathrm{~g}$. Ysang (2009) reported that the total phenols content of non-tanin sorghums ranged 
from $90-1820 \mathrm{mg}$ gallic acid equivalent (GAE)/100 g sample. Afify et al. (2012) found that the losses of total phenols ranged between $21.97 \%$ and 28.30 in sorghum after soaking.

Several possible reasons have been suggested for reductions in polyphenol concentrations upon soaking. Losses may result simply from leaching into the soak water (Deshpande et al., 1982; Igbedioh et al., 1995): Losses may also be attributed to decreases in extractability, as lower molecular weight phenolic compounds polymerize, thus becoming insoluble in water (Deshpande et al., 1982). Other investigators (Bravo, 1998) have attributed the losses to binding of polyphenols with other organic substances such as carbohydrate or protein. Alternatively, during the period of soaking, the enzyme polyphenol oxidase may be activated, resulting in degradation and consequent losses of polyphenols (Jood et al., 1987; Jood et al., 1998 and Saxena et al., 2003).

This reduction of total phenols, after soaking may be attributing to leaching of phenols into the soaking medium (Afify et al., 2012). The results approved with Nwosu (2010) showed that this reduction was expected as soaking helped in the removal of the soluble antinutrients like tannins. Akillioglu (2010) reported that the result of longer soaking duration leading to more phenolics diffuse outside.

The effect of germination on phenolic contents of wheat, corn and sorghum are shown in Table (2) and Fig. 1. Phenolic compounds content in wheat was decreased gradually during germination period. The total phenolics content in wheat grains was decreased to $76.14,69.66$, and $58.91 \%$ of its initial value of control after 24,36 , and $48 \mathrm{hr}$ of germination, respectively. In corn grains, the phenolic content decreased after 24, 36, and $48 \mathrm{hr}$ of germination to $85.09,65.96$, and $56.05 \%$ of its control value, respectively. While in sorghum the phenolic content decreased to $72,70.43$, and $60.07 \%$ of its value in the raw grains after the same germination periods, respectively. Decreases in the polyphenol contents during germination have been reported by several authors for pulses (Mc-Grath et al., 1982; Rao and Deosthale, 1982 and Osuntogun et al., 1989). These decreases may be attributed to increase the activity of polyphenol oxidase and other catabolic enzymes as observed by (Kruger, 1976) for wheat. On contrary; El-Refai et al (2012) found that increasing germination period of barely and oats grains increased total phenolic compounds, antioxidants activity and flavonoids content.

\section{Effect of soaking and germination on antioxidant activity:}

The results presented in Table (3) and Fig. 2 show the effect of soaking as free radical scavenging activity in wheat, corn and sorghum grains. In raw samples, sorghum has higher antioxidant activity than that of wheat and corn grains. DPPH radicals scavenging activity were $37.28,34.44$, and $33.05 \%$ for raw sorghum, wheat, and corn grains, respectively. DPPH scavenging activity of wheat, corn and sorghum was decreased during soaking period. It was decreased with about $6.85,13.49$ and $16.84 \%$ of the original value after soaking for $12 \mathrm{hr}$ for wheat, corn and sorghum respectively. These results are in the same line with those of Afify et al. 
(2012) they reported that DPPH scavenging activity in raw sorghum varied from 21.72 to $27.69 \%$.

Table (2): Effect of soaking and germination process on phenolic compounds content $\mathrm{mg}(\mathrm{GAE}) / \mathbf{1 0 0 g}$ in wheat, corn and sorghum (Mean \pm SD)

\begin{tabular}{|c|c|c|c|c|c|c|}
\hline \multirow{2}{*}{ Samples } & \multirow{2}{*}{ Control } & Soaking & \multicolumn{4}{|c|}{ Germination } \\
\cline { 3 - 7 } & & $\mathbf{1 2} \mathbf{~ h r}$ & $\mathbf{1 2} \mathbf{~ h r}$ & $\mathbf{2 4} \mathbf{~ h r}$ & $\mathbf{3 6} \mathbf{~ h r}$ & $\mathbf{4 8} \mathbf{~ h r}$ \\
\hline Wheat & $381.4 \pm 6.9$ & $323.5 \pm 10.61$ & $338.6 \pm 11.27$ & $290.4 \pm 3.66$ & $265.7 \pm 5.51$ & $224.7 \pm 9.77$ \\
\hline Corn & $288.5 \pm 7.07$ & $271.3 \pm 4.24$ & $290.6 \pm 3.09$ & $245.5 \pm 9.52$ & $190.3 \pm 5.1$ & $161.7 \pm 6.58$ \\
\hline Sorghum & $204 \pm 11.31$ & $173.6 \pm 2.55$ & $159.4 \pm 2.79$ & $149.6 \pm 6.93$ & $143.5 \pm 5.46$ & $130.7 \pm 8.78$ \\
\hline
\end{tabular}

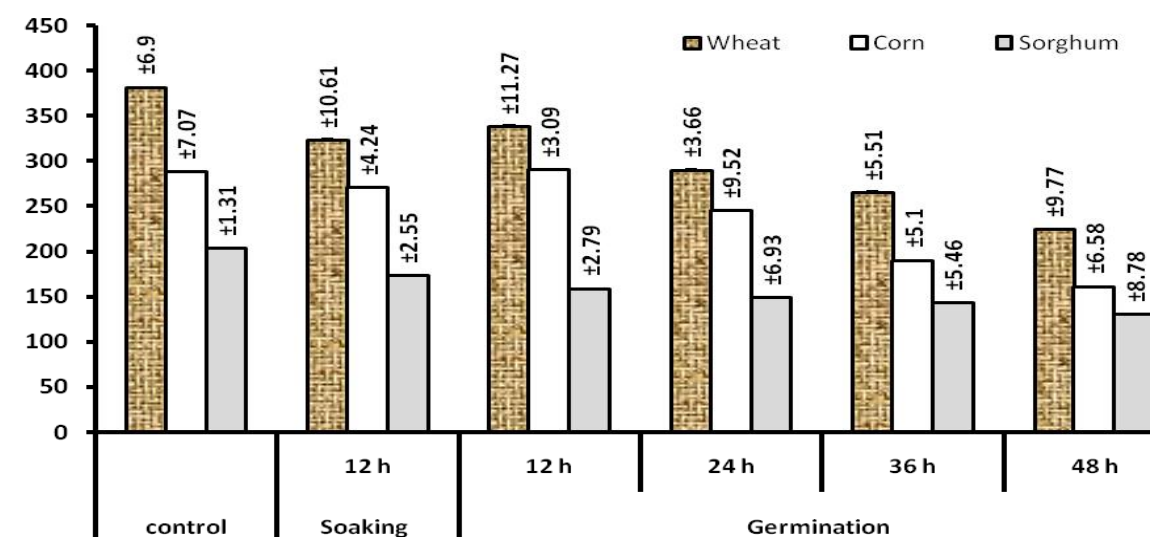

Fig. (1): Effect of soaking and germination time in phenolic content $\mathrm{mg}$ $(G A E) / 100 g$ in Wheat, Corn and Sorghum.

The DPPH radical scavenging activity in the studied grains was gradually decreased during germination period (Table 3 and Fig 2). these values were decreased by $21.60,20.12$ and $30.79 \%$ of its initial values in wheat, corn and sorghum, respectively. Results revealed that the highest losses were recorded in sorghum grains compared with other grains. These results are in the line with these reported by Bolívar et al. (2010). They found that antioxidant activity for wheat grains decreased after germinated for 7 days. Donkor, et al. (2012) reported that the radical scavenging activities of the phenolic extracts were between $13 \%$ and $73 \%$ for non-germinated and $14 \%$ and $53 \%$ for germinated of seven selected commercially important grains including wheat and sorghum. In contrary, Lo'pez-Amoro's, et al. (2006) found that peas and beans undergo a significant increase in antioxidant activity after germination, and El-Refai et al (2012) found also that the antioxidant activity was increased by increasing the germination period of barely and oats grains. 
Ramadan, B. R. et al.

Table (3): Effect of soaking and germination process in \%DPPH scavenging activity in wheat, corn and sorghum.

\begin{tabular}{|c|c|c|c|c|c|c|}
\hline \multirow{2}{*}{ Samples } & \multirow{2}{*}{ Control } & Soaking & \multicolumn{5}{|c|}{ Germination } \\
\cline { 3 - 7 } & & $\mathbf{1 2} \mathbf{~ h r}$ & $\mathbf{1 2} \mathbf{~ h r}$ & $\mathbf{2 4} \mathbf{~ r}$ & $\mathbf{3 6} \mathbf{~ h r}$ & $\mathbf{4 8} \mathbf{~ h r}$ \\
\hline Wheat & $34.44 \pm 0.8$ & $32.08 \pm 3.3$ & $31.89 \pm 3.54$ & $30.74 \pm 3.8$ & $30.63 \pm 1.88$ & $27.0 \pm 1.34$ \\
\hline Corn & $33.05 \pm 1.94$ & $28.59 \pm 1.41$ & $30.11 \pm 3.83$ & $28.16 \pm 4.4$ & $26.86 \pm 2.45$ & $26.4 \pm 1.83$ \\
\hline Sorghum & $37.28 \pm 0.89$ & $31.00 \pm 3.58$ & $31.09 \pm 1.11$ & $28.41 \pm 1.63$ & $27.56 \pm 1.31$ & $25.8 \pm 1.5$ \\
\hline
\end{tabular}

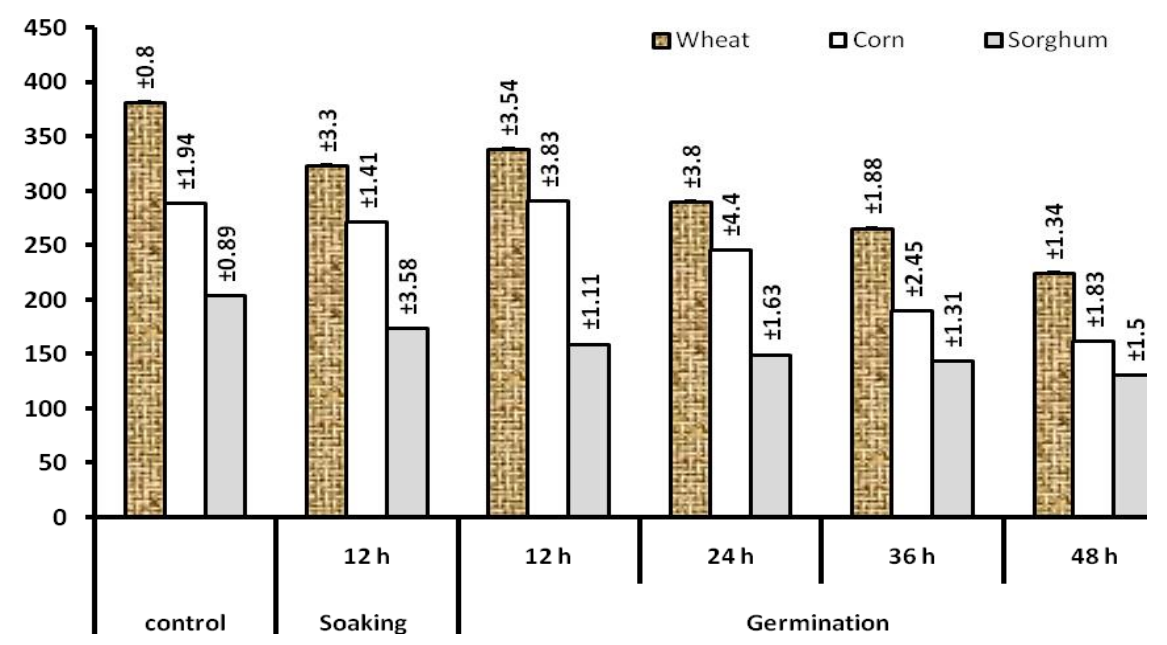

Fig. (2): Effect of germination time in \% DPPH scavenging activity in wheat, corn and sorghum.

\section{CONCLUSIONS}

Soaking and germination processes showed significant decrease in total phenolic compounds and antioxidant activity. Losses of total phenols during soaking for $12 \mathrm{hr}$ ranged from $5.96-15.18 \%$ of its initial values of raw materials; in wheat, sorghum and corn. Germination process for $48 \mathrm{hr}$ led to decrement of total phenols ranged from $39.3-43.95 \%$ in investigated cereal grains of its initial values in raw grains. DPPH radical scavenging activity decreased during soaking and germination processes.

\section{REFERENCES}

Abdel-Gawad, A.S (1993): Effect of domestic processing on oligosaccharide content of some dry legume seeds. Food. Chem., 46: 25-31.

Afify, A. M. R.; El-Beltagi, H. S.; Samiha, M. A. and Azza, A. O. (2012): Biochemical changes in phenols, flavonoids, tannins, vitamin $E$, B carotene and antioxidant activity during soaking of three white sorghum varieties. Asian Pacific J. Tropical Biomedicine: 203-209. 
Akillioglu, G. H. and Karakaya, S. (2010): Changes in total phenols, total flavonoids, and antioxidant activities of common beans and pinto beans after soaking, cooking, and in vitro digestion process. Food Sci. Biotechnol. 19(3): 633-639.

AOAC (1980): Association of Official Analytical Chemists. Official methods of analysis. (13th Ed.). Washington., D.C. U.S.A.

AOAC (2000): Association of Official Analytical Chemists. Official methods of analysis. (17th Ed.). Washington., D.C. U.S.A.

Bolívar, A.; Cevallos-Casals, 1. and Zevallos, L. C. (2010): Impact of germination on phenolic content and antioxidant activity of 13 edible seed species. Food Chem. 119: 1485-1490.

Brand-Williams, W.; M. Cuvelier and C. Berset (1995). Use of a free radical method to evaluate antioxidant activity. Lebensm. Wiss. Tech., 28; 2530.

Bravo, L. (1998): Chemistry, dietary sources, metabolism and nutritional significance. Nutrition Reviews, 56(11): 317-333.

Deshpande, S. S.; Sathe, S. K.; Salunkhe, D. K. and Cornforth, D. P. (1982): Effects of dehulling on phytic acid, polyphenols and enzyme inhibitors of dry beans (Phaseolus vulgaris): J. Food Sci., 47(6): 1846-1850.

Donkor, O. N; Stojanovska, L.; Ginn, P.; Ashton, J. and Vasiljevic, T. (2012): Germinatedgrains -sources of bioactive compounds. Food Chem. Accepted 14 May 2012. Available online 22 May 2012.

El-Refai, A.A; El-Bastawesy, Amal: El-Ashaal, Eman (2012). Effect of Germination process on the chemical and biological active compounds of Barely and Oat grains. J. Food and Dairy Sci., Mansourra Univ. 3 in print.

Fadahunsi, I. F. (2009): the effect of soaking, boiling and fermentation with Rhizopus oligosporus on the water-soluble vitamin content of Bambara groundnut. Pak J. Nutr., 8(6): 835-840.

FCTE (2006): food composition table for Egypt. National Nutrition Institute, Cairo, A.R.E. Second edition: 8-10.

Glennie, C.W. (1983): Polyphenol changes in sorghum during malting. J. Agric. Food Chem., 31: 1295-1299.

Igbedioh, S. O.; Shaire, S. and Aderiye, B. J. I. (1995): Effects of processing on total phenols and proximate composition of pigeon pea (Cajanus cajan) and climbing bean (Vigna umbellate): J. Food Sci. and Tech., 32(6): 497-500.

Jood, S.; Bishnoi, S. and Segal, S. (1998): Effect of processing on nutritional and anti nutritional factors of moongbean cultivars. J. Food Biochem., 22: 245-257.

Jood, S.; Chauhan, B. M., and Kapoor, A. C. (1987): Polyphenols of chickpea and blackgram as affected by domestic processing and cooking methods. J. Sci. Food and Agric., 39: 145-149.

Kaukovirta-Norja, A.; Wilhemson, A. and Poutanen, K. (2004): Germination: A means to improve the functionality of oat. Agricultural and Food Science, 13: 100-112. 
Kruger, J. E. (1976): Changes in the polyphenol oxidase of wheat during kernel growth and maturation. Cereal Chemistry, 53: 201-211.

Kumar, M.; Kumar, S.; Kaur, S. (2011): Investigations on DNA protective and antioxidant potential of chloroform and ethyl acetate fractions of Koelreuteria paniculata Laxm. Afr J Pharm Pharmacol, 5(3): 421-427.

Lo' pez-Amoro,' s. M . L.; Herna' ndez, T. and Estrella, I. (2006): Effect of germination on legume phenolic compounds and their antioxidant activity J. Food Composition and Analysis, 19: 277-283.

Mc-Grath, R. M.; Kaluza, W. Z.; Daiber, K. H.; van-des Hiet, W. B. and Glennie, C. W. (1982): Polyphenols of sorghum grain, their changes during malting and their inhibitory nature. J. Agric. and Food Chem., 30: 450-456.

Nwosu, J. N. (2010): Effect of soaking, blanching and cooking on the antinutritional properties of asparagus bean (Vigna sesquipedis) flour. Nat. Sci., 8 (8): 163-167.

Osuntogun, B. A.; Adewusi, S. R. A.; Ogundiwin, J. O. and Nwasike, C. C. (1989): Effect of cultivar, steeping, and malting on tannin, total poly phenol, and cyanide content of Nigerian sorghum. Cereal Chemistry, 66 (2): 87-89.

Oufnac, D. S. (2006): Determination of antioxidant capacity in corn germ, wheat germ and wheat bran using solvent and microwave-assisted solvent extraction, M.Sc. Thesis, Food Science Dept., Fac., Agric. and Mechanical., Louisiana State Univ., USA.

Ragaee, S.; Abdel-Aal and Noaman, M. (2006): Antioxidant activity and nutrien composition of selected cereals for food use. Food Chem. 98: 32-38.

Rao, P. U. and Deosthale, Y. G. (1982): Tannin content of pulses, varietal differences and effects of germination and cooking. J. Sci. of Food and Agric., 33: 1013-1018.

Saxena, A. K., Chadha, M. and Sharma, S. (2003): Nutrients and antinutrients in chickpea (Cicer arietinum L.) cultivars after soaking and pressure cooking. J. Food Sci and Tech., 40 (5): 493-497.

Shweta, K. A.; Shobha, A. U. and Padmini, G. (2010): Polyphenols and tannins in Indian pulses: Effect of soaking, germination and pressure cooking. Food Research International $43: 526-530$

Sorour, M. A. (1997). Studies on the reduction of phytic acid contents in Egyptian bread by deferent fermentation methods. Ph.D. Thesis, Fac. of Agric., Assuit Univ., Egypt.

Temple, N. J. (2000): Antioxidants and disease: more questions than answers. Nutrition Research, 20: 449-459.

Tome, M. M.; Murcia, M. A.; Frega, N.; Ruggieri, S.; Jime'nez, A. M.; Roses, F. (2004): Evaluation of antioxidant capacity of cereal brans. J. Agric. and Food Chem., 52: 4690-4699.

Velioglu ,Y.S.; Mazza, G. L. and Oomah, B. D. (1998): Antioxidant activity and total phenolics in selected fruits, vegetables, and grain products. $\mathrm{J}$. Agric and Food Chem., 46: 4113-4117.

Willet, W. C. (1994): Diet and health: what should we eat. Sci., 254: 532-537. 
Yang L. (2009): Chemopreventive potential of sorghum with different phenolic profiles. (M.Sc. thesis): Texas University: 1-117.

Youssef, M.K,E. and Ramadan, B.R (1987): Nutritive value of Dates. Technical Bull. No. 15, September, Fac. Agric., Assuit Univ., Egypt.

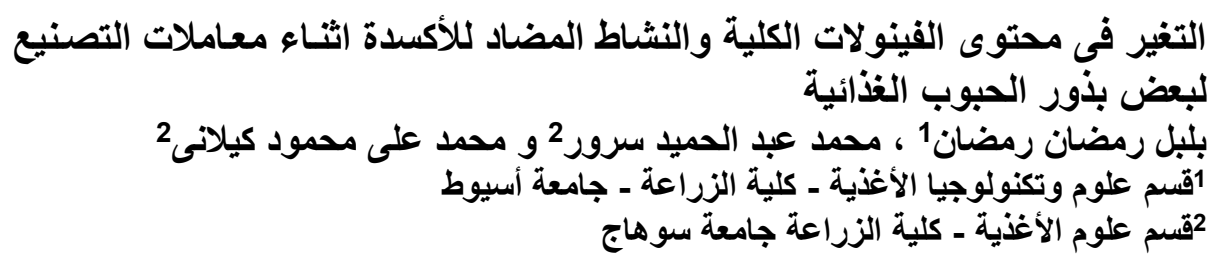

يهذف هذا البحث إلي دراسة التغير فى المحتوى الكلى للفينو لات وكذللك النشاط المضاد

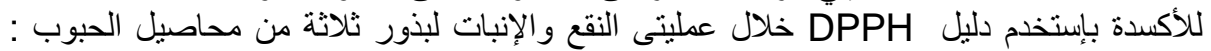

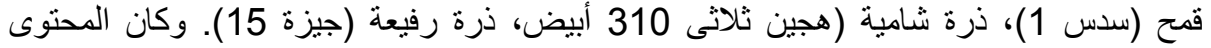

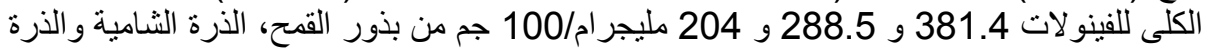

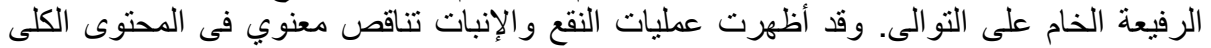

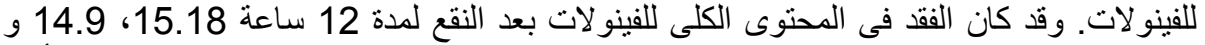

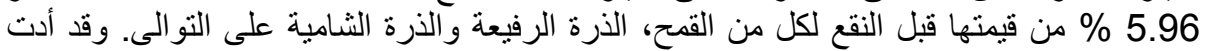

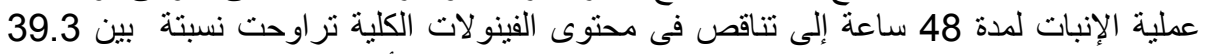

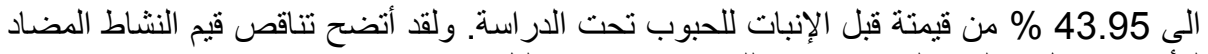

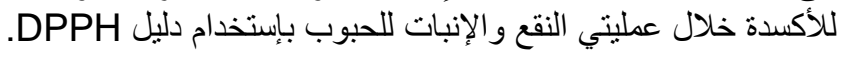

كلية الزراعة ـ ـ جامعة المنصورة

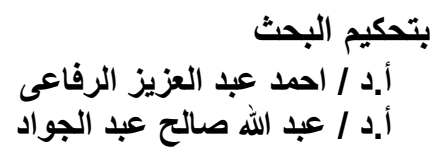

